\title{
Depression and Hypothyroidism in a Population-Based Study of Iranian Women
}

\author{
ABBAS TAVALAEI ZAVAREH ${ }^{1}$, ROHOLLAH JOMHOURI ${ }^{2}$, HADI SHAHRAD BEJESTANI ${ }^{3}$, \\ MAHMOUD ARSHAD ${ }^{3}$, MOHAMMADALI DANESHMAND ${ }^{4}$, \\ HOSSEIN ZIAEI $^{2}$, NEDA BABADI ${ }^{2}$, MARZIEH AMIRI ${ }^{5}$ \\ ${ }^{1}$ Department of Psychiatry, Baghiatallah Medical University, Tehran, Iran \\ ${ }^{2}$ Department of Internal Medicine, Rasoul-e-Akram Hospital, \\ Iran University of Medical Science, Tehran, Iran \\ ${ }^{3}$ Department of Endocrinology, Rasoul-e-Akram Hospital, \\ Iran University of Medical Science, Tehran, Iran \\ ${ }^{4}$ Royal Perth Hospital, Perth, WA \\ ${ }^{5}$ Khomein Research and Science Branch, \\ Islamic Azad University of Khnomein, Arak, Iran
}

\begin{abstract}
Background. Recent biochemical and physiological investigations have focused on the fundament of mood disorders in thyroid dysfunction. The present study aimed to address depressive disorder in a sample of Iranian hypothyroid women compared to euthyroid individuals.

Methods. Thirty consecutive hypothyroid female patients aged 25 to 40 years who referred to the Endocrinology and Metabolism Clinic at Rasoul-e-Akram Hospital in Tehran within a four-month period in 2015 were assessed. Thirty healthy euthyroid subjects matched for sex, age, and educational level were selected as the control. For assessment of depression status, Depression Anxiety Stress Scale-21 (DASS-21) was employed.

Results. The study showed higher mean depression score in hypothyroid patients when compared to euthyroid ones $(13.8 \pm 9.5$ versus $5.8 \pm 5.2, \mathrm{p}=0.010)$. No significant association was revealed between mean depression score and patients' education level $(p=0.627)$, age $(p=0.967)$, occupation status $(\mathrm{p}=0.211)$, and marital status $(\mathrm{p}=0.556)$.

Conclusion. Hypothyroid women are predisposed to depressive symptoms independent of their baseline demographic and socioeconomic characteristics.
\end{abstract}

Key words: depression; hypothyroidism; symptom; euthyroid; mood disorder; biochemical marker.

\section{INTRODUCTION}

Thyroid hormones have a powerful affection on metabolism. In hypothyroidism, many organs and internal systems slow down that lead to a wide range of symptoms - including depression. People over 60 may have only one symptom - such as mood impairment and depression. However, researchers are not entirely sure why there is a link between hypothyroidism and depression.

The relationship between mood disorders and thyroid dysfunction has been long described as a high incidence of nervous affectations in thyroid abnormalities firstly about two hundred years ago [1]. Later, the term of myxedema madness was introduced for describing mental status in patients with hypothyroidism [2]. Today, it has been well established that thyroid dysfunction especially hypothyroidism may significantly impact mental status especially mood state and cognitive conditions in hypothyroid patients. Fortunately, the proper anti- hypothyroidism treatment regimen seems to be effective to remove mood disturbances and thus depressive disorders are usually reversible by appropriate management. Furthermore, most of mood disturbances have a subtle not overt nature that although subclinical hypothyroidism may occur in up to $40 \%$ of patients with hypothyroidism, depression may be accompanied with only $4 \%$ of those with overt hypothyroidism [3]

Some biochemical and physiological investtigations have focused the fundament of mood disorders in thyroid dysfunction. It has been shown that the majority of patients with major depressive mood do not suffer changes in thyroid-related biochemical markers [4, 5]. However, in some animal studies, it has been revealed that the gene heterozygous mutations in thyroid hormone receptors (such as THR $\alpha-1$ ) can increase depressive behavior responsive to continuous thyroid hormones administration [6]. In addition, reduced concentration of thyroid hormone transport protein in CSF fluid of 
depressive patients compared with normal condition [7-9]. All of these evidences emphasized the hypothesis regarding significant association between depressive mood and hypothyroidism. Hence, the present study aimed to address depressive disorder in a sample of Iranian hypothyroid patients compared to euthyroid individuals.

\section{MATERIAL AND METHODS}

\section{STUDY POPULATION}

Thirty consecutive hypothyroid female patients aged 25 to 40 years who referred to Endocrinology and Metabolism Clinic at Rasoul-e-Akram Hospital in Tehran within a four-month period in 2015 were assessed. The included patients had no risk factors for psychological disorders and were regularly treated with levothyroxine within the last six months with normal serum TSH level. Also, thirty healthy euthyroid subjects matched for sex, age, and educational level were selected as the control. These controls had no history of thyroid disorders, diabetes mellitus, hyperlipidemia, anemia or other major risk factors for psychological disorders. For removing confounding effect of sex and age factors, all female patients aged 25 to 40 years were included into the study. The study protocol was approved by the ethics committee at Iran University of Medical Silences which conforms to the provisions of the Declaration of Helsinki, and written informed consents were taken from all subjects.

\section{STUDY MEASUREMENT}

For assessment of depression status, Depression Anxiety Stress Scale-21 (DASS-21) was employed. The DASS consists of three self-report scales that have been designed to measure the negative emotional states of depression, anxiety and stress that the component of depression was used in this study to assess depression and its severity. The DASS-21 is a brief 21 item version of the full DASS, which originally consisted of 42 items [10]. The depression DASS-21 scale contains seven items representing the dimensions of depression. Participants were asked to rate the extent to which they experienced depression state over the past week on a 4-point likert rating scale. Sub-scale scores are derived by totaling the scores. No items are reverse scored. Scores for each sub-scale are multiplied by two to ensure consistent interpretation with the longer 42 item version [10]. The DASS manual provides a series of cut-off values to classify individuals into severity rating categories. These severity ratings are based on percentile scores, with $0-78$ classified as 'normal', $78-87$ as 'mild', 87-95 as 'moderate', 95-98 as 'severe', and 98-100 as 'extremely severe' [10]. Samani et al. in a study on Iranian population [11] reported alpha value for the DASS-21 was 0.83 for depression. Internal consistency in the present study was explored for depression scale of the DASS-21, and Cronbach's alpha coefficient was adequate as 0.81 . In the present study, first, the objectives of the study were described briefly to participants. Then, baseline characteristics and clinical data of study subjects were collected by interviewing. Then all women in both case and control groups were invited to complete the questionnaire under the supervision of the researcher.

\section{STATISTICAL ANALYSIS}

Results were presented as mean \pm standard deviation (SD) for quantitative variables and were summarized by absolute frequencies and percentages for categorical variables. Categorical variables were compared using chi-square test or Fisher's exact test when more than $20 \%$ of cells with expected count of less than 5 were observed. Quantitative variables were also compared with t test or MannWhitney $U$ test. For the statistical analysis, the statistical software SPSS version 16.0 for windows (SPSS Inc., Chicago, IL) was used. P values of 0.05 or less were considered statistically significant.

\section{STUDY LIMITATION}

Our study had a limitation that is a small number of patients.

\section{RESULTS}

As shown in Table 1, compared to euthyroid group, the hypothyroid patients were significantly older with lower educational level. Also, students and employed ones were more categorized in euthyroid group, while housewives were more observed in hypothyroid group. There was no difference in marital status between hypothyroid and euthyroid groups. The study showed higher 
mean depression score in hypothyroid patients when compared to euthyroid ones $(13.8 \pm 9.5$ versus $5.8 \pm 5.2, p=0.010)$ regarding association between depression status and patients' baseline characteristics
(Table 2), no significant association was revealed between mean depression score and patients' education level $(p=0.627)$, age $(p=0.967)$, occupation status $(\mathrm{p}=0.211)$, and marital status $(\mathrm{p}=0.556)$.

Table 1

Baseline characteristics and clinical data of case and control groups

\begin{tabular}{lccc}
\hline \multicolumn{1}{c}{ Item } & $\begin{array}{c}\text { Hypothyroid group } \\
(\mathbf{n}=\mathbf{3 0})\end{array}$ & $\begin{array}{c}\text { Euthyroid group } \\
(\mathbf{n}=\mathbf{3 0})\end{array}$ & P-value \\
\hline Mean age, year & $35.50 \pm 5.46$ & $30.30 \pm 5.11$ & $<0.001$ \\
\hline Occupation state & $22(73.3)$ & $8(26.7)$ & $<0.001$ \\
\hline Housewife & $5(16.7)$ & $11(36.7)$ & \\
\hline Employed & $1(3.3)$ & $3(10.0)$ & \\
\hline Physician & $1(3.3)$ & $0(0.0)$ & \\
\hline Farmer & $1(3.3)$ & $7(23.3)$ & \\
\hline Student & $0(0.0)$ & $1(3.3)$ & \\
\hline Teacher & & $7(23.0)$ & $<0.001$ \\
\hline Marital status & $8(26.0)$ & $23(76.0)$ & \\
\hline Single & $22(74.0)$ & $1(3.0)$ & \\
\hline Married & & $4(13.0)$ & \\
\hline Education level & $12(40.0)$ & $17(56.0)$ & \\
\hline Undergraduate & $11(36.0)$ & $8(26.0)$ & \\
\hline Diploma & $6(20.0)$ & & \\
\hline Bachelor degree & $1(3.0)$ & & \\
\hline Higher level & & & \\
\hline
\end{tabular}

Table 2

Association between depression and baseline parameters

\begin{tabular}{lcccc}
\hline \multicolumn{1}{c}{ Variable } & Mean of squares & F & P value & Partial Eta \\
\hline Education level & 116.728 & 2.350 & 0.627 & 0.164 \\
\hline Age & 0.088 & 0.002 & 0.967 & $<0.001$ \\
\hline Occupation state & 75.470 & 1.520 & 0.211 & 0.112 \\
\hline
\end{tabular}

\section{DISCUSSION}

In line with our results that emphasizes strong association between hypothyroidism and manifestation of depression, almost all previous similar studies could demonstrate this correlation. In a recent study by Ittermann et al. [12], it was found a positive association between untreated diagnosed hypothyroidism and the BDI depression score, while a distinct interaction was revealed between childhood maltreatment and thyroid disorders in modifying the association on depression. In another recent study by Ojha et al. [13], thyroid dysfunction also showed a positive correlation with depression severity. Interestingly, similar to our survey, they found no association between different sociodemographic variables and depression. In another study by Demartini et al. [14], two-third of hypothyroid patients suffered depressive symptoms. Guimarães et al. [15] in a population-based study of middle-aged Brazilian women showed that women with increased level of TSH had a threefold chance of presenting depressive symptoms compared to those with normal levels of TSH, while the risk for clinical hypothyroidism was about 8.7 times of euthyroid individuals. Chueire et al. [16] also showed that subclinical hypothyroidism increased the risk for a patient to present depression more than four times. According to the present evidences, the association between both overt and subclinical hypothyroidism and depressive symptoms is demonstrated regardless of gender and age factors. However, it seems that advanced age may be accompanied with increased risk for depression. Some baseline mechanisms have been described for susceptibility of hypothyroid patients to depressive disorders. It has been well shown that hypothyroidism exhibits considerable alterations in blood flow and glucose metabolism in the brain. In addition, those with major depression have structural abnormalities of the hippocampus that can affect memory performance [17]. Also, thyroid peroxidase antibodies are directly associated with trait markers of depression. In fact, depressive symptoms may be a main component of thyroid failure. Moreover, glucose homeostasis and rapid weight loss have been associated to thyroid 
hormones and increased depressive symptoms indicating a causative relationship between thyroid dysfunction and increased predisposing to depression [17]. However, despite clear association between hypothyroidism and depressive symptoms, antihypothyroidism therapy could not effectively remove depressive symptoms especially in the elderly that may be influenced by different baseline factors such as gene variants and genetic polymorphisms related to thyroid hormone receptors.

Although we did not assess the beneficial effects of anti-hypothyroidism treatment on removing depressive symptoms, conflicting results have been obtained in this subject. A meta-analysis of early double-blind placebo controlled trials showed that treatment with T3 supplements was effective in accelerating the clinical response to tricyclic antidepressants in patients with non-refractory depression especially in female patients [18]. However, some studies assessing the newer antidepressant agents, such as the selective serotonin reuptake inhibitors (SSRIs) in combination with T3 have yielded confounding results [19]. Furthermore, it has been shown by Baumgartner et al. [20] that administration of thyroxine in its supra-physiological doses could be effective in approximately half of the depressive patients. Thus, the beneficial effects of thyroid treatments on severity of depressive symptoms need to investigate more to achieve optimal thyroid drug regimen. However, because the limitation of the study is small sample size, further studies are needed.

\section{CONCLUSION}

In conclusion, in the present study performed on hypothyroid women, we showed an association between hypothyroidism status and depressive condition. More interestingly, the revealed association between hypothyroidism and depression was independent to baseline characteristics including age, educational level, and occupational state. Thus, it seems that the mechanisms of appearing depressive in hypothyroid patients may be influenced by other potential factors such as gene predisposition.

Acknowledgement. The authors wish to thank Rasoul-eAkram Hospital Clinical Research Development Center for technically supported implementation of the project.

Introducere. Studii recente s-au concentrat pe ipoteza disfuncției tiroidiene drept fundament al tulburărilor psihiatrice. Studiul de față şi-a propus evaluarea simptomelor depresive la o populație de femei hipotiroidiene comparativ cu indivizi eutiroidieni.

Metode. 30 de paciente consecutive hipotiroidiene cu vârste cuprinse intre 25 şi 40 ani ce s-au prezentat la clinica Rasoul-e-Akram din Teheran pe parcursul a 4 luni în cursul anului 2015 au fost evaluate. 30 de martori sănătoşi şi imperecheați după gen, vârstă şi nivel educațional au fost selecționați. Pentru evaluarea depresiei a fost folosit chestionarul DASS-21 (Depression Anxiety Stress Scale-21).

Rezultate. Scoruri semnificativ statistic mai mari ale DASS-21 au fost inregistrate la pacientele hipotiroidiene comparativ cu martorii eutiroidieni (13.8 \pm 9.5 versus $5.8 \pm 5.2, p=0.010)$. Nu s-au găsit asocieri între scorul de depresie şi nivelul educațional $(p=0.627)$, vârstă $(p=0.967)$, statusul marital $(p=0.556)$.

Concluzii. Femeilie hipotiroidiene au predispoziție pentru dezvoltarea simptomelor depresive independent de statusul socioeconomic sau a unor caracteristici bazale.

Correspondence to: Marzieh Amiri, M.A, Research and Science Branch, Islamic Azad University, Arak, Iran Tel: 00989127272624

E-mail: amiri.m1387@yahoo.com

\section{REFERENCES}

1. HAGE MP, AZAR ST. The Link between Thyroid Function and Depression. J Thyroid Res. 2012; 2012:590648.

2. D'HAENEN H., BOER J.A.D., and WILLNER P. Biological Psychiatry, vol. 1, Wiley, Chichester, UK, 2002.

3. WOLKOWITZ OM and ROTHSCHILD AJ. Psychoneuroendocrinology: The Scientific Basis of Clinical Practice, American Psychiatric, Washington, DC, USA, $1^{\text {st }}$ edition, 2003. 
4. LOOSEN PT. Hormones of the hypothalamic-pituitary-thyroid axis: a psychoneuroendocrine perspective. Pharmacopsychiatry.1986; 19: 401-15.

5. VANDOOLAEGHE E, MAES M, VANDEVYVERE J, NEELS H. Hypothalamic-pituitary-thyroid-axis function in treatment resistant depression. Journal of Affective Disorders.1997; 43: 143-50.

6. PILHATSCH M, WINTER C, NORDSTROM K, VENNSTROM B, BAUER M, JUCKEL G. Increased depressive behaviour in mice harboring the mutant thyroid hormone receptor alpha 1. Behavioural Brain Research. 2010; 214:187-92.

7. HATTERER JA, HERBERT JC, HIDAKA C, ROOSE SP, GORMAN JM. CSF transthyretin in patients with depression. American Journal of Psychiatry. 1993; 150: 813-5.

8. SULLIVAN GM, HATTERER JA, HERBERT J, et al. Low levels of transthyretin in the CSF of depressed patients. American Journal of Psychiatry.1999; 156:710-5.

9. SULLIVAN GM, MANN JJ, OQUENDO MA, LO ES, COOPER TB, GORMAN JM. Low cerebrospinal fluid transthyretin levels in depression: correlations with suicidal ideation and low serotonin function. Biological Psychiatry. 2006; 60: 500-6.

10. CRAWFORD JR, HENRY JD. The Depression Anxiety Stress Scale (DASS): Normative data and latent structure in a large nonclinical sample. Br J Clin Psychol. 2003; 42:111-31.

11. SAMANI S, JOKAR B. Study the validity and reliability of the Iranian version of the Depression, Anxiety, Stress Scale. J Soc Humanities Shiraz University, 2007:263.

12. ITTERMANN T, VÖLZKE H, BAUMEISTER SE, APPEL K, GRABE HJ. Diagnosed thyroid disorders are associated with depression and anxiety. Soc Psychiatry Psychiatr Epidemiol. 2015; 50(9):1417-25.

13. OJHA SP, DHUNGANA S, CHAPAGAIN M, TULACHAN P. Association of thyroid dysfunction with depression in a teaching hospital. J Nepal Health Res Counc. 2013; 11(23):30-4.

14. DEMARTINI B, MASU A, SCARONE S, PONTIROLI AE, GAMBINI O. Prevalence of depression in patients affected by subclinical hypothyroidism. Panminerva Med. 2010; 52(4):277-82.

15. GUIMARÃES JM, DE SOUZA LOPES C, BAIMA J, SICHIERI R. Depression symptoms and hypothyroidism in a populationbased study of middle-aged Brazilian women. J Affect Disord. 2009; 117(1-2):120-3.

16. CHUEIRE VB, ROMALDINI JH, WARD LS. Subclinical hypothyroidism increases the risk for depression in the elderly. Arch Gerontol Geriatr. 2007; 44(1): 21-8.

17. DUNTAS LH, MAILLIS A. Hypothyroidism and depression: salient aspects of pathogenesis and management. Minerva Endocrinol. 2013; 38(4):365-77.

18. ALTSHULER LL, BAUER M, FRYE MA, et al. Does thyroid supplementation accelerate tricyclic antidepressant response? A review and meta-analysis of the literature. American Journal of Psychiatry.2001; 158:1617-22.

19. COOPER-KAZAZ R, VAN DER DEURE WM, MEDICI M, et al. Preliminary evidence that a functional polymorphism in type 1 deiodinase is associated with enhanced potentiation of the antidepressant effect of sertraline by triiodothyronine. Journal of Affective Disorders. 2009; 116: 113-6.

20. BAUMGARTNER A. Thyroxine and the treatment of affective disorders: an overview of the results of basic and clinical research. International Journal of Neuropsychopharmacology.2000; 3: 149-65.

Received March 8, 2016 